\title{
Forum
}

\section{Sicut Sol Inter Astra: Timely Latin in the Aftermath of the Fire at Notre-Dame}

\author{
Evan Dutmer
}

Keywords: Medieval Latin, Pedagogy, Notre-Dame

This piece originated as an article in In Medias Res on 31 May 2019 and has been updated for the Journal of Classics Teaching. The author would like to acknowledge the helpful feedback from the editors at In Medias Res and The Journal of Classics Teaching on earlier drafts of this essay. Their suggestions helped produce a superior piece.

On April 15 2019, about a month ago, the Cathedral of NotreDame burned in Paris. I had just finished teaching for the day when I heard the news. I opened my phone and saw a text from my dad: 'Notre Dame (Cathedral) is burning down.'

I was in a daze. In my Latin III class, we had just finished reading from Ovid's opening invocation in the Metamorphoses 1.1-2:

\section{in nova fert animus mutatas dicere formas corpora}

(Or in Arthur Golding's sonorous sixteenth-century rendering: 'Of shapes transformde to bodies straunge, I purpose to entreate' (Golding 21).

I had planned for us to read from the myth of Echo and Narcissus the next day (Metamorphoses 3.339-510). But it felt so strange to continue on the same path, as if Notre-Dame had not burned down the night before. Could I do more?

Latin literature - any literature, for that matter — can seem timeless, reaching out and imposing itself in our current moment. But when the moment calls out and begs instead for timeliness, where should we look?

It is not an easy question, and there is no easy answer. But I have come to expect that timely Latin can come from unexpected places. In this case, I found the words for the Great Fire at Notre-Dame not in antiquity, but in the near-contemporary report on the Cathedral from a little-known medieval author.

For me and my students, this was an exciting, elucidating experience. I read and was moved (along with my students) by Latin far removed from the canon I've grown accustomed to; together, our

Author of correspondence: Evan Dutmer, Evan Dutmer is Instructor in Latin and Ethics at the Culver Academies in Culver, IN, USA.

E-mail: evan.dutmer@culver.org

Cite this article: Dutmer E, (2020). Sicut Sol Inter Astra: Timely Latin in the Aftermath of the Fire at Notre-Dame. The Journal of Classics Teaching 21, 81-83. https://doi. org/10.1017/S2058631020000033 understanding of world events today changed because of our reading Latin; and, last, for my students, many realised for the first time that Latin did not die out with the Romans.

Instead, Latin's afterlife was very real to my students that April day-when it reached out to us not as a dead language, but a world one. ${ }^{2}$ Latin, that day, had taken on a new shape.

In 1323, John of Jandun, a medieval scholastic philosopher and interpreter of Averroes and Aristotle, and a notable contemporary and associate of the political philosopher Marsilius of Padua, composed an encomium to the new cathedral in Paris in his work Tractatus de laudibus Parisius. ${ }^{3}$

I came across the Tractatus on the night of the fire, when a simple internet search had led me to Michael T. Davis' English translation. ${ }^{4}$ I quickly found the Latin reproduced in an article in Gesta (Inglis, 2003) and got to work adapting it for my students.

My eyes glided over the Latin, and I came across this:

Inter quas [ecclesias Parisienses] illa terribilissima gloriosissime Virginis Dei genitricis Marie ecclesia non immerito, sicut sol inter astra, prefulget.

Among the churches of Paris, the Church of the most glorious Virgin Mary, Mother of God, surely the most aweful (terribilissima), shines brilliantly, as a sun among stars (author's translation).

When I read this, I stopped. I could not help but think of the images I had seen of the blaze, uncontrolled, devouring the roof and the spire, pitched against a hazy Paris sunset. Notre-Dame had become terrible. It was affecting - eerie, even - to read these words in conjunction with the day's images so present in my mind.

Notre-Dame, then, made us tremble on 15 April 2019. But why was it 'terrible' for Jandun? Jandun could have used venerabilissima, ornatissima, pulcherrima - yet he chooses terribilissima. According to Lewis and Short's Latin Dictionary, terribilis came to mean 'demanding reverence, venerable' in late Latin, but it seems Jandun - just a few decades after its construction - might have been trying to capture Notre-Dame's peculiar 'awe-ful' power to impose on us, to shake us, to not leave us alone. To make us tremble. With or without physical fire, it touches us with an internal one.

In the $18^{\text {th }}$ century, Edmund Burke drew a distinction between the 'Beautiful' and the 'Sublime' in his famous Philosophical Enquiry 
into the Origin of Our Ideas of the Sublime and the Beautiful: the Beautiful arises from pleasure, the Sublime, from pain.

In the 19th century, John Ruskin, following in the Burkean tradition, summarises the position aptly in his Seven Lamps of Architecture, where he discusses the 'Lamp of Power' in architecture:

It will generally happen that [beautiful works of architecture] fall into two broad classes: the one characterised by an exceeding preciousness and delicacy, to which we recur with a sense of affectionate admiration; and the other by a severe, and in many cases mysterious, majesty, which we remember with an undiminished awe, like that felt at the presence and operation of some great Spiritual Power (Ruskin, 1890).

Predating Ruskin by some 500 years, did Jandun mean to bring attention to the presence of 'some great Spiritual Power' - a 'severe' majesty - at Notre-Dame by his using terribilissima? Was he calling it sublime?

It surely seems so - especially if we turn to a Latin text with which Jandun would have been most familiar: the Vulgate Bible. In a stirring example in Genesis 28:17, just after Jacob's dream of the Ladder into Heaven, Jerome's Vulgate reads:

pavensque, "quam terribilis," inquit, "est locus iste! non est hic aliud nisi domus Dei et porta caeli!

And he was afraid, and said, "How awesome is this place! This is none other than the house of God, and this is the gate of heaven."

Jacob called the holy place he had come upon Bethel. Jandun called the holy place he had come upon Notre-Dame.

This aforementioned sentence - where Jandun remarks on the exceeding glory and 'terror' of Notre-Dame in comparison to all other Parisian churches - convinced me of this text's continuing relevance for young readers. I knew it would have an impact on my students.

That night, I finished writing up two graded summaries of Jandun's piece. I follow many other Latin teachers in providing graded summaries-sometimes called embedded readings-for my students (see, for example, Sears and Ballestrini, 2019). These allow students to work up to an original text in Latin by reading a number of easier and more direct learner's texts. These act as proficiency-oriented stepping stones to the original text, helping to make the reading accessible to all readers present in the classroom. I had two sections - one of Latin I, one of Latin III. ${ }^{5}$ I wanted to share Jandun with both.

On 16 April 2019, I slowly read his words aloud with my students - step by step we established the meanings of unfamiliar words (often Medieval or Ecclesiastical); meanwhile, I projected selections from the Tractatus to the front of the room with photographs of Notre-Dame; before and after, resplendent and then ruined.

Then we came upon Jandun's closing exclamation, which I reproduce here in full and unadapted (again, my translation follows):

O quam salubres in illis oratoriis Deo potentissimo preces fundunt, cum spiritales et interne puritates ipsorum precantium corporalibus et externis oratoriorum munditiis proportionaliter correspondent!

O quam placide omnipotentissimo Deo in illis tabernaculis laudes canuntur, cum ipsorum corda canentium sunt amenis tabernaculorum picturis analogice virtutibus venustata!

O quam acceptabilia gloriosissimo Deo super hec altara holocausta parantur, cum ipsorum sacrificantium vita, correspondente deauratione altarium claritate, resplendet ${ }^{5}[6]$
O how salutary are the prayers that pour out in those oratories to God most-powerful, when the inner, spiritual purities of the worshippers correspond proportionally to the corporal, external ornaments of the sanctuary!

O how gentle are those praises sung to God omnipotent in those tabernacles, when the hearts themselves of the singers are beautified in harmony with the portraits in the sanctuaries!

O how agreeable to God most glorious are sacrifices prepared on those altars, when the life of the priest himself shines with a gilded brilliance equal to that of the altar! (Author's translation).

Jandun's Latin sparkled; it glinted in a new light, refracted through the dark glass of history, into the eyes and ears of students trying to make sense of the tragedy.

I remember the delight on my students' faces when they realised it was Latin, and not French, in which de Jandun chose to express himself in the Tractatus de laudibus Parisius. We sometimes forget how for our students, most of whom are not particularly drawn to knowledge of Latin's millennia-long history, this can be a moment of revelation. Latin is a language in which real people, relatable people, from all across history, chose to express themselves, to be understood. And not always in neo-classical modes: Tractatus de laudibus Parisius is not a treatise of imitation - there is no invocation of the Muses or an attempt to make Notre-Dame into a new Pantheon - rather, Jandun talks about his lived experience of the power and beauty of NotreDame in Latin he meant to be understood by his peers.

I remember that night I heard a newscaster say that Notre-Dame was more than a place of Catholic Christian worship. Rather, it was a human monument for the whole world: 'A symbol on which to place our greatest hopes.?

So, too, for Latin. Its architecture - like Notre-Dame's became the kind of thing people used (and continue to use!) to pin up their hopes, dreams, worries, frustrations, ideas, desires. For thousands of years it was a language in whose architecture people around the world expressed their everyday cares and their innermost thoughts. And, of course, through the Mass and the influence of the Catholic Church, it gave to millions a nearly universal language of prayer in Europe and around the world. In this case Jandun gives us a walking tour of the most beautiful sights in Paris not in his mother tongue, but in Latin.

And this wasn't just any Latin, but Latin far outside the typical, prescribed canon. In fact, this Latin came over 1,300 years later than Caesar's, Cicero's or Virgil's. And it was this Latin on that day which alighted in students a reverence and an awe not only for one of the world's great cultural landmarks, but for the power of language to change and reshape our worldview, our very way of looking at things, many hundreds of years after it is first spoken or written down.

To continue to breathe life into Latin, we, as teachers, must do this. We have the power-the responsibility, even-to reshape Latin, consider it in all its permutations (especially those unappreciated and unexpected ones, the ones not to be found in textbooks), to connect its disparate, zigzagging afterlives into a compelling, understandable story for our students.

They are eager for it. And, we, as teachers, have more inspiration than we think. Listen to them-what compels them? What confuses them? What scares them?

For about half an hour, then, one of those people, John of Jandun, reached out to us - a high school Latin teacher and about a dozen students - as we read his words. He told us about his Notre-Dame as we now looked on ours, changed forever. He spoke, we listened; he exclaimed, we heard. We traded passage for photograph until we had finished. 
There then was reverent silence.

in nova fert animus mutatas dicere formas corpora...

[For those interested in pursuing these topics further: the Latin text used here for the Tractatus de Laudibus Parisius - which is odd in places, including the title - is from the appendix of Erik Inglis's Gesta article, which, in turn, derives from Paris et ses historiens, Le Roux de Lincy and Tisserand, eds., 44, 46, 48 (Paris, 1867). For some excellent recent scholarship on the sublime (in the work of Kant and Schopenhauer, in particular), see Sandra Shapshay, 'The Problem and Promise of the Sublime: Lessons from Kant and Schopenhauer' in Suffering Art Gladly (Palgrave MacMillan, 2014) and her entry on 'Schopenhauer's Aesthetics' in the online Stanford Encyclopedia of Philosophy (2018).]

\section{References}

Burke E (Reprint, 1998) Philosophical Enquiry into the Origin of Our Ideas of the Sublime and the Beautiful. Oxford: Oxford World's Classics.

Davis M "In Praise of Paris: a description of the city in 1323." The Late Medieval City: Architecture and Urbanism. Available online: http://www.ruf.rice. edu/ lmc/praiseofparis_web/gallery-01.html. 2005. Accessed 30 January 2020.

Golding A (1904) Shakespeare's Ovid: Being Arthur Golding's Translation of the Metamorphoses. Ed. W.H.D. Rouse. London: De La More Press.

Inglis E (2003) "Gothic Architecture and a Scholastic: Jean de Jandun's Tractatus de laudibus Parisius (1323)." Gesta 42 (1): 63-85.

Leonhardt J (2013) Latin: Story of a World Language. Cambridge: Harvard University Press.

Pike M (2016).Latin in the $21^{\text {st }}$ Century. The Journal of Classics Teaching 17 (33): 6-7. Available online: https://www.cambridge.org/core/journals/journal-ofclassics-teaching/article/latin-in-the-21st-century/9CFD78D62A5EE90 530611807232E4454. Accessed 30 January 2020.

Pring R (2016) My Philosophy of Education and How it Might Relate to Classical Subjects. The Journal of Classics Teaching 17 (33): 1-5. Available online: https://www.cambridge.org/core/journals/journal-of-classicsteaching/article/my-philosophy-of-education-and-how-it-might-relate-toclassical-subjects/9EBE2DCC8A7BBD908DB425D71DBA7036. Accessed 30 January 2020.

Ruskin J (1849) The Seven Lamps of Architecture. London: The Waverly Book Company.

Sears L and Ballestrini K (2019) Adapting antiquity: using tiered texts to increase Latin reading proficiency. The Journal of Classics Teaching 20 (39): 71-77. Available online: https://www.cambridge.org/core/journals/journal-ofclassics-teaching/listing? q=sears\&_csrf=x6JgJyM2-1cGbBfXhjJL_NjHyeZStQ GNAivo\&searchWithinIds=614D38B0B2E9358263A484E6E6CA4A94. Accessed 30 January 2020.

Tatum J (2014) Arion: A Journal of Humanities and the Classics 22 (2): 75-96.

\section{Notes}

1 For some Latinists, this brings about a moment of insecurity. Just how can Latin be timely? (We know it's lasted-but who's to say it will last?) Latin's seeming identity crisis has elicited some powerful reflections on its continued relevance and ability to shape and reshape our view of the world today. See, for example, Pike 2016 and Pring 2016. At the intersection of Classics and literary theory, Classical Receptions Studies takes this question as its point of departure (for a helpful introduction, see Tatum 2014).

2 I borrow the coining from Leonhardt's masterful Latin: Story of a World Language (Harvard 2013).

3 For the text of Jandun's Tractatus, see the appendix in Inglis 2003.

4 Found on the webpage for the 2005 conference 'The Late Medieval City: Architecture and Urbanism' held at Rice University (Davis).

5 At my institution, Latin I signifies the first year of Latin study (generally year one of upper or high school). Latin III, accordingly, signifies the third year of Latin study.

6 Appendix to Inglis 2003.

7 I haven't been able to find the precise newscast-but I was listening to MSNBC that evening in my car. 